\title{
'Vacation for your teeth' - dental tourists in Hungary from the perspective of Hungarian dentists
}

\author{
E. Kovacs ${ }^{* 1}$ and G. Szocska ${ }^{1}$
}

to shed light on patient motives.

\begin{abstract}
Background Hungary has become a popular destination for foreign patients in the last two decades, particularly in dental care. Since 2008, increasing prices in Western Europe coupled with Hungary's accessibility and availability of dental treatment, has meant the country has become a leader in 'dental tourism'. As the quality of care in Hungary is high and prices are more affordable than in Western Europe, and due to the freedom of movement of people, services and goods within the EU, patient flow into Hungary has increased progressively. Objectives The aim of this article is to provide comprehensive empirical evidence from the perspective of a recipient country in dental tourism. Methods $\mathrm{A}$ questionnaire survey was conducted among Hungarian dentists $(n=273)$. Qualitative in-depth interviews were conducted with representatives of dental professional bodies $(n=10)$. Both research methods aimed to elicit dentists' views on the presence of dental tourism - particularly the push and pull factors (for example, source countries, competitors, information sources, patient motivation). Results The findings show that there are several reasons why Hungary could maintain a leading position in dental tourism. First, the cost/benefit ratio is outstanding. The affordable price and value for money were already recognised in the early 1990s and were appreciated even before Hungary joined the EU. Secondly, the high quality of Hungary's dental profession: a) dental professionals in Hungary are well-qualified dental practitioners who have received high level dental training; b) dental professional standards are up-to-date and often supervised; $c$ ) in Hungary dental technology, the quality of materials and equipment used in dental practices is of European level quality. The rate of complications in dental care is around 5\%, similar to other European countries. Finally, previous treatment experiences are positive and patient satisfaction levels are high. More and more patients seek care in Hungary, and more and more patients state that they would be willing to return for further treatment in the future.
\end{abstract}

\section{INTRODUCTION}

\section{DENTAL CARE IN HUNGARY}

Dental care in Hungary is divided into three service types: 1) primary dental care, including, among other things, dental screening, school dental services and dental services for pregnant women; 2) specialist dental care; and 3) out-of-hours dental services. Primary dental care is organised on a territorial basis. Most dental services in Hungary are available free of charge within the single-payer health insurance system if the patient is entitled for supply

${ }^{1}$ Health Services Management Training Centre Semmelweis University Kútvölgyi út 2, 1125 Budapest, Hungary

*Correspondence to: Eszter Kovacs

Email: kovacs.eszter@emk.sote.hu

\section{Refereed Paper}

Accepted 30 May 2013

DOI: 10.1038/sj.bdj.2013.995

${ }^{\circledR}$ British Dental Journal 2013; 215: 415-418 in the district. ${ }^{1}$ Nevertheless, private provision is dominant in dental care in Hungary for domestic and international patients. Dental tourism often occurs through the private sector; therefore, the development of private dental care capacities could be facilitated by cross-border dental care and health tourism in general.

\section{CROSS-BORDER DENTAL CARE}

Cross-border dental care appeared in the early 1990s when patients from neighbouring regions crossed the border seeking dental care. This brought a significant increase in patient turnover in Western Hungary. The phenomenon was originally limited to the border regions with Austria - 'border hopping' - where patients pay for private dental services directly. ${ }^{2-6}$

Besides Western Hungary, Budapest became the second most significant area in dental tourism; ${ }^{5}$ around $80 \%$ of the dental offices in Transdanubia opened branches in the capital. Budapest became the second biggest supplier in the area of dental tourism. Due to low cost air travel, Hungary is now easily accessible from every part of Europe, not only neighbouring countries but those further afield..$^{2,7-10}$ Hungary gained its leading position in dental tourism in Europe in 2008. ${ }^{10,11,13}$ Today, dental tourism has a 20-year tradition in Hungary and Hungarian dental care is widely seen as reliable. ${ }^{12}$

\section{PREVIOUS RESEARCH}

There is a growing body of literature attempting to reveal the features of health and medical tourism; however, substantial evidence is still lacking in academic research. Several studies have aimed to examine the booming medical tourism industry from different angles, which 


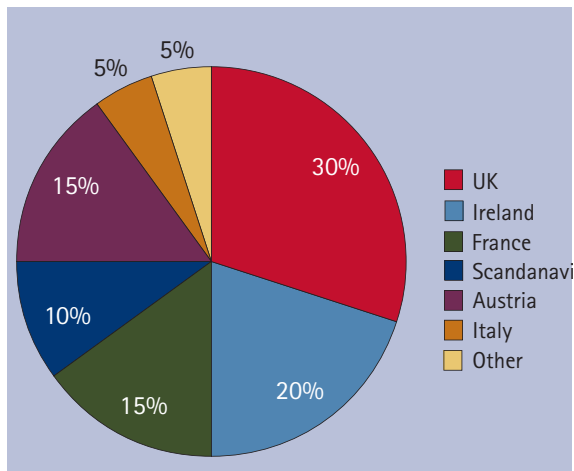

Fig. 1 'Sending' countries in Europe in 2010 (Source: Attila Kámán)

contribute to an enhanced understanding of the phenomenon, but evidence is often vague and sporadic, and contains estimates.

Articles can be found dealing with terminology, namely health and medical tourism and its history. Other studies concentrate on the economic perspective providing estimates regarding the volume of patient mobility, benefits for 'sending' and 'recipient' countries, and the economic growth stemming from patient mobility. Another current approach is the policy perspective with the introduction of the 24/2011 EU Directive on patients' rights. Articles looking at patient motivation usually focus on the procedure-based, the travel-based and the costbased components through discussion of issues such as whether the treatment is planned, available; affordable/reimbursable; easily accessible; quality assured and accredited with high level technology; safe with minimised risks; conducted by well-qualified professionals or combined with a vacation etc. In terms of travelling considerations are made on whether the destination country is: time consuming to reach; people speak the required language; politically stable; taking care of religious diversities; providing good communication - understandable and comprehensive information etc. Of the information flow, reliability and continuity are highlighted as crucial factors. Today valid data are available from research on patient satisfaction. For instance - with the focus on Hungarian dental treatments - patient satisfaction rates in general show an overwhelmingly positive picture, with a high level of satisfaction (above 95\%). Research conducted among German patients ${ }^{14-18}$ revealed that

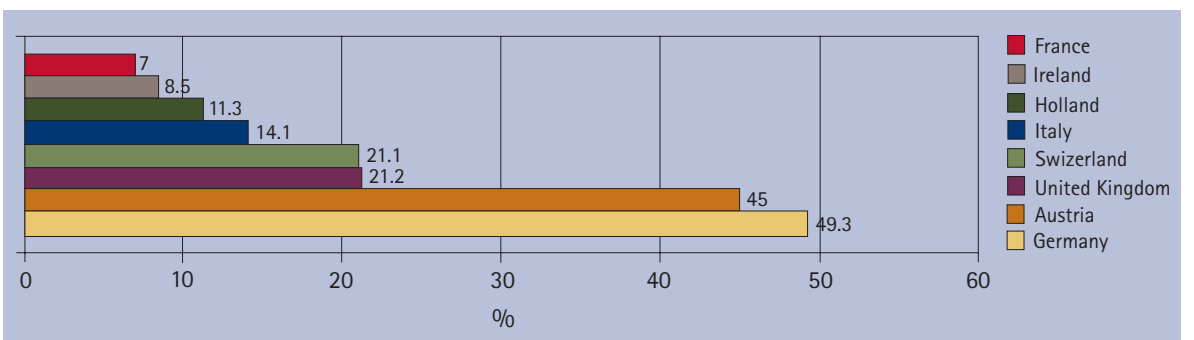

Fig. 2 Source countries of the patient turnover in dental practices (\%)

the vast majority of patients are highly satisfied with the dental service, dentists and dental treatments provided in Hungary.

\section{METHODS AND PROCEDURE}

Qualitative and quantitative analysis were carried out in order to gain an insight into the phenomenon of dental tourism in Hungary (research tools were prepared and discussed by the ECAB research team). First, leaders or representatives of relevant dental professional bodies were interviewed by a semi-structured interview on dental tourism and quality issues. Secondly, a questionnaire survey was conducted among active dentists using total population sampling as a type of purposive sampling technique. The survey was available online and was also distributed in collaboration with several dental professional bodies by post, for example, it was sent to all recipients of the Journal of The Hungarian Dentist by the Dental Section of the Hungarian Medical Chamber. The final sample consisted of 273 questionnaires that were analysed.

\section{FINDINGS}

\section{MAIN SENDING COUNTRIES}

Based on the literature, the findings of the questionnaire survey and the conducted interviews, the main 'sending' and 'recipient' countries can be identified. First of all, it is very important to note that in Hungary there are two crucial areas where dentists are treating foreign patients (it is important to note that these dental offices treat Hungarian and foreign patients). Since dental tourism started as cross-border dental care in Western Hungary, this area is still remarkable for Austrian and German patients. This area - due to its proximity to Austria - specialises in German-speaking patients. The other remarkable area is the capital, Budapest, due to the location of the airport. Patients from Scandinavia, the
UK and Ireland, Switzerland, France and Italy arrive in Budapest for dental care (Fig. 1). ${ }^{2,7,11,18}$

Figure 2 shows the source countries based on the experiences of active Hungarian dentists in their own practice, answering the question: which countries do your foreign patients come from? Dentists stated that the main source countries in their dental practices are Germany, Austria, the UK and Switzerland (Fig. 2).

In terms of Hungary's competitors, Poland, the Czech Republic, Slovenia, Bulgaria, Romania, Turkey and Spain might be mentioned. ${ }^{10}$ See Figure 3 for estimated rates.

The questionnaire survey showed that a significant number of dentists in Hungary treated foreign patients. Our sample showed similar rates to other research regarding the number of dental offices treating foreign patients, that is, $20 \%$ of dental offices. ${ }^{3,10,11}$

Figure 4 shows that nearly 24\% of respondents treat foreign patients in their dental practice. In an average month 61.7\% of dentists treat mostly Hungarian patients with health insurance. The rate of treating mostly Hungarian private patients is $12.5 \%$. In addition, $77.4 \%$ mentioned treating foreigners in low volume, namely $0-10 \%$ of their patients per month. Treating foreign patients in emergency cases showed a very low level (3.6\%).

\section{PATIENT INFORMATION SOURCES}

Ninety-five percent of respondents emphasised that patients arrive via their own means and only 5\% indicated that they arrive on an organised trip, thus, it is important to consider where patients receive information about dental care abroad. Three considerations must be underlined here: friends' recommendations, the Internet, and medical tourism agencies (Fig. 5). Friends' recommendations or 'word-of-mouth' is the most trustworthy 


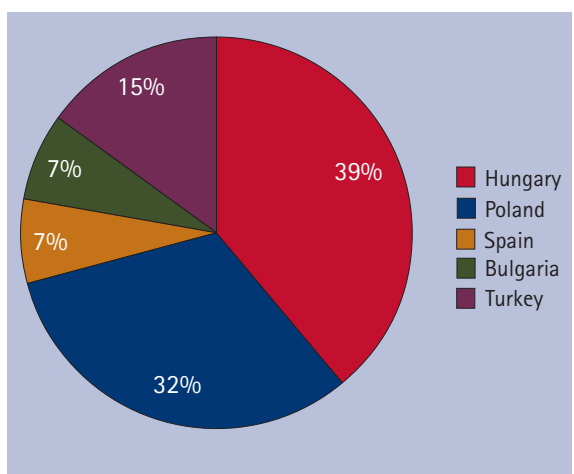

Fig. 3 Recipient countries in Europe in 2007 (Source: Tolnai et al. ${ }^{19}$ )

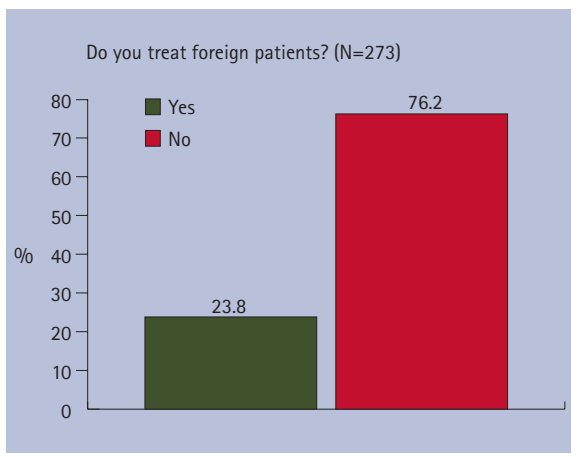

Fig. 4 Rate of treating foreign patients (\%)

source; good experiences generate more and more satisfied patients. Patients' experiences and evaluations can usually be read on dental practice websites. The Internet provides widespread information on dental treatments in Hungary. Medical tourism agencies also operate and provide useful information, often in collaboration with travel agencies. Surprisingly, the majority of the interviewed dental practices do not collaborate with medical tourism agencies. Only $4.4 \%$ of the respondents were familiar with medical tourism agencies, and only $1.8 \%$ had a contract with those agencies (Fig. 5).

Another activity from dental offices that increases trust is to open an office abroad where patients have the opportunity to meet the dentists during pre-consultation. This means that the treatment plan might be prepared in the home country, before travelling abroad. Dental offices abroad might provide aftercare and liability, redress as well.

Although pre-consultations ensure trust, the volume of treatment plans prepared before the patient travels to the destination country is 23.3\%; therefore, treatment plans after arrival are more common, $76.7 \%$. The language of the treatment plan is mostly English or in the patient's mother

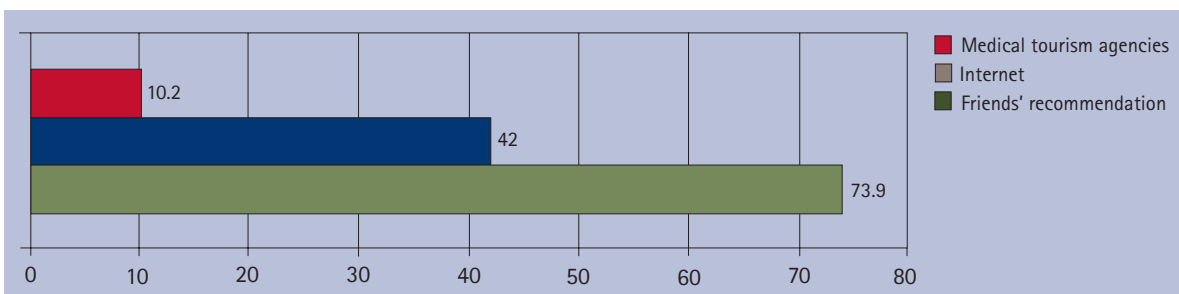

Fig. 5 Patients' information sources (\%)

tongue (42.1\%-42.1\% respectively). Similarly, doctor-patient communication is mostly in English during treatments (55\%) and 30\% in the patient's mother tongue. Regarding aftercare, it mostly takes place in Hungary (72.1\%), 5\% abroad (mostly in the UK).

\section{PATIENT MOTIVATION}

There are several reasons why patients decide to have dental treatment abroad. In England, around 40,000-50,000 patients seek dental care abroad. In Austria and Switzerland, the lack of health insurance could be a significant patient motivation. In the Ukraine there is a lack of treatments available.

Of the main patient motivations, affordable prices, good service (good quality, professionalism, advanced technology) and the combination of treatment with a holiday or cultural programmes play a significant role. ${ }^{3}$ Klar also underlines the importance of the ability to plan. ${ }^{18}$ For patients it is remarkable to see in advance how much time the treatment takes, how the treatment process is carried out, how many times they have to see the dentist and what the aftercare is like. .,20-22 $^{2}$

\section{ADVANTAGES AND DISADVAN- TAGES OF DENTAL TOURISM}

Most opinions emphasise the advantages of dental tourism both for patients and for the healthcare system; several respondents said there are no disadvantages to dental tourism.

For patients the following advantages can be mentioned: they receive good quality treatment packages from wellqualified dental professionals for a reasonable price, thus the cost/benefit ratio is excellent. Hungary has provided good quality treatment for foreigners in the last 20 years since cross-border care started. Patient satisfaction rates are high, and positive treatment experiences definitely facilitate the rates of returning for new treatments. ${ }^{14}$ Another advantage is the combination of dental treatment with a holiday, which is also growing in popularity. $3,13,14,18,23,24$ Dentists stated that after reasonable prices (83.5\%) and good quality (35\%), combining a treatment with a holiday (27.4\%) and avoiding waiting lists (27\%) count significantly towards a patient's decision to travel abroad. In the questionnaire survey the following were highlighted regarding advantages for patients: $86.2 \%$ saving money - around $€ 1,000$, a real patient motivation; saving time is also crucial, namely, 24\% think time plays a significant role (36.7\% value a saving of one week, 33.3\% one month); patients are also motivated by easy accessibility of treatments (19.3\%) and special treatments (17.7\%).

In summary, saving time and money, quick and easy access to good quality dental care increase the rates of patients travelling abroad for dental treatment.

For the healthcare system dental tourism might bring development, hi-tech equipment, and may trigger continuous technological developments. Dental technology can be improved via increasing patient flow (22\%) and income (68.2\%). Forty percent of respondents stated that they had more advanced, higher quality equipment due to increased income. Further, dental offices create new jobs (13.7\%), prevent Hungarian dentists from leaving the country, and might reverse 'brain-drain' (9.7\%). Dental tourism - via technological development - also has a good impact on continuous dental education, as skills and knowledge need to be up-to-date. Moreover, dental tourism also facilitates growth in other sectors of the tourist industry, which triggers economic growth (12.8\%). ${ }^{10,21}$

As far as disadvantages are concerned, only the patient's perspective was emphasised, namely time pressure. Receiving aftercare in case of complications or lack of aftercare were mentioned; however, 
most of the time patients are aware of the whole dental treatment process in advance, and unexpected complication is rare, around 5\%, similar to other European countries. In the survey $72.1 \%$ of the dentists stated that they provide aftercare for foreign patients. Time pressure leads us to overtreatment and aftercare issues, thus, more and more dental offices open dental offices abroad where pre-consultation and aftercare can be provided without returning to Hungary. This also supports liability and redress issues.

\section{CONCLUSION}

This article aimed to provide comprehensive empirical evidence from the perspective of a 'recipient' country in dental tourism. The findings show that several reasons can be listed for Hungary gaining the leading position as a destination country in dental tourism. First, the cost/benefit ratio is outstanding. The affordable price and value for money has been appreciated for the last three decades. Secondly, the high quality of the dental profession is highlighted: dental professionals are well-qualified, and Hungary has a long tradition in dental training and practice. Further, dental professional standards are up-to-date and European level dental technology is used. Finally, previous treatment experiences are positive and patient satisfaction levels are high. More and more patients seek care in Hungary, and more and more patients state that they are willing to return for another treatment in the future. The volume of patients arriving in Hungary shows an increasing tendency towards recommendation facilitated by word-of-mouth.
Based on the findings of this research project, it would seem that the phenomenon of patient mobility within European member states is beneficial for all affected parties and in particular for a positive patient experience.

We thank all questionnaire respondents who took time to provide us with the requested information. We particularly wish to thank all the institutions participating in the study: Dental Section of the Hungarian Medical Chamber; Hungarian Dental Association; National Advisory Board of Healthcare - Dental and Oral Disease Department and Council (previously Professional Advisory body of Dental and Oral Disease); National Institute of Oral and Maxillofacial Diseases; National Dental Public Health Authority - Chief Dental Officer; National Committee for Hungarian Dentistry. Other dental bodies interviewed: the Association of Leading Hungarian Dental Clinics and the Hungarian Dental Tourism Company.

The present paper is based on Kovacs E, Szocska G, Torok B, Ragany K. (2013) Why is Hungary the main destination country in dental tourism? Why do patients choose Hungary for dental care? Hungarian Case Study on dental care and patient flow. ECAB project (Grant agreement 242058). http://english.hsmtc.hu/site/wp-content/ uploads/2013/02/Final_case_study_web.pdf

1. Gaál P, Szigeti S, Csere M, Gaskins M, Panteli D. Hungary health system review. Health Syst Transit 2011; 13: 1-266.

2. Balázs $P$, Österle A. Cross-border patient migration in the Hungarian dentistry. (Külföldiek fogorvosi kezelése Magyarországon) Stomatologia Hungarica (Fogorvosi Szemle) 2008; 101: 193-202.

3. Council of European Dentists. Responses to European Commission consultation regarding community action on health services. CED Position Paper, January 2007.

4. Österle A. Health care across borders: Austria and its new EU neighbours. J Eur Soc Policy 2007: 17: 112-124.

5. Österle A, Balázs P, Delgado J. Travelling for teeth: characteristics and perspectives of dental health tourism in Hungary. Br Dent J 2009: 206: 425-428.

6. Herrick D M. Medical tourism: Global competition in health care. 2007. http://w.medretreat.com/ templates/UserFiles/Documents/Medical\%20 Tourism\%20-\%20NCPA\%20Report.pdf

7. Kámán A. Dental tourism as the key sector in health tourism. Paper presented at the congress 'Hungary's opportunities in the international medical tourism'
3 May 2010.

8. Michalkó G, Rátz T, Hinek M. Spatial differences in Hungarian medical tourism supply based on services' online presence. Hungarian Geographical Bulletin 2012; 61: 31-47.

9. Ruszinkó A. Medical professions in health tourism, popular services. Paper presented at the congress 'Hungary's opportunities in the international medical tourism', 3 May 2010.

10. Szúts L. Dental tourism: the new 'Hungaricum' Hungarian J Nursing Theory Practice (Nővér) 2010; 23: 32-39.

11. Szücs L. Application for development of dental practices and dental tourism. (Pályázati források a fogászatok és a fogászati turizmus fejlesztésére) Dental News (Dental Hirbörze) 2012; 8: 10-14.

12. Keckley P H, Underwood H R. Medical tourism. Consumers in search of value. Deloitte Centre for Health Solutions, 2008.

13. Caballero-Danell S, Mugomba C. Medical tourism and its entrepreneurial opportunities - a conceptual framework for entry into the industry. Thesis. Göteborg University: School of Business, Economics and Law, 2007.

14. Wagner C, Moser F, Hohn A, Dobrick K, Verheyen F. Europabefragung 2012. Geplante grenzüberschreitende Versorgung in der EU Ärzte und Zahnärzte aus Sicht der TKVersicherten. WINEG Wissen 03. Hamburg: Techniker Krankenkasse, 2013.

15. Wagner C, Dobrick K, Verheyen F. EU Cross-Border Health Care Survey 2010. WINEG Wissen 02. Hamburg: Techniker Krankenkasse, 2011

16. Wagner C, Verheyen F. TK Europe Survey. German patients en route to Europe 2009. WINEG, Hamburg: Techniker Krankenkasse, 2009

17. Wagner C, Schwarz A. TK Analysis of EU Crossborder Healthcare in 2007. WINEG, Hamburg: Techniker Krankenkasse, 2008.

18. Klar A. Gesundheitstourismus in Europa - Eine empirische Transaktionskosten-Analyse. Manuscript of the PhD thesis, 2012

19. Tolnai Zs., Billik B, Fuchs P. Hungary and the dental tourism. (Magyarország és a fogászati turizmus). Health Economics (Egészségügyi Gazdasági Szemle) 2009; 4: 34-40

20. Ehrbeck, T, Guevara, C, Mango P D. Mapping the market for medical travel. McKinsley Quarterly 2008; 1-11

21. Horowitz M D, Rosenweig J A. Medical tourism health care in the global economy. The Physician Executive 2007: 24-30.

22. Turner L. Cross-border dental care: 'dental tourism' and patient mobility. Br Dent J 2008; 204: 553-554.

23. Barrowman R.A, Grubor D, Chandu A. Dental implant tourism. Aust Dent J 2010; 55: 441-445.

24. Klar A. Comments on TK Europe Survey. PhD study on planned treatment abroad. Brussels: EHMA Roundtable, 17 November 2010 